\title{
COMPARATIVE STUDY OF THE EFFECTS OF MEDETOMIDINE AND XYLAZINE IN CATS AND REVERSAL WITH ATIPAMEZOLE
}

Cleber Salesse Cardoso ${ }^{1}$, Elisa Bacco Jorge ${ }^{2}$, Aline Bozzetto dos Santos ${ }^{3}$, João Paulo Silva Smerdel ${ }^{3}$, Luis Roberto Almeida Gabriel Filho ${ }^{4}$, Silvia Franco Andrade ${ }^{5}$

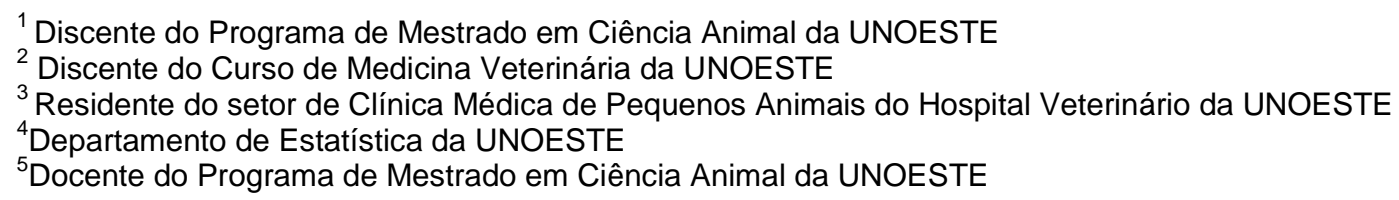

\section{ABSTRACT}

The objectives of this study were to compare the clinical effects and glycemia induced by medetomidine and xylazine in healthy cats and to demonstrate the reversal of the effects by atipamezole. A prospective blinded randomized experimental trial was used with twenty-four healthy adult cats. The animals were allocated into 4 groups of 6 animals each to receive by intramuscular route (IM): Group M (medetomidine $-50 \mu \mathrm{g} / \mathrm{kg}$ ); Group X (xylazine - $1.1 \mathrm{mg} / \mathrm{kg}$ ); Group MA (medetomidine - $50 \mu \mathrm{g} / \mathrm{kg}$ and 60 minutes later atipamezole - 0.2 $\mathrm{mg} / \mathrm{kg}$ ); Group XA (xylazine - $1.1 \mathrm{mg} / \mathrm{kg}$ and 60 minutes later atipamezole $-0.2 \mathrm{mg} / \mathrm{kg}$ ). Rectal temperature, respiratory rate, heart rate, systolic arterial pressure, electrocardiogram, intraocular pressure, degree of sedation were measured at $0,30,60,120$ and 180 minutes, and the serum glucose concentration was measured at $0,60,120$ and 180 minutes. The xylazine at a dose of $1.1 \mathrm{mg} / \mathrm{kg}$ and medetomidine at a dose of $50 \mu \mathrm{g} / \mathrm{kg}$ (both intramuscular) induced hypothermia, decreased heart rate, respiration and blood pressure and also 1st-degree A-V block in some cats, but it did not interfere significantly with intraocular pressure. The medetomidine induced a more pronounced hypothermia, sedation and hyperglycemia than xylazine in cats. The atipamezole was an excellent antagonist of the effects induced by medetomidine and xylazine in cats. Also, it did not interfere with the intraocular pressure values.

Keywords: medetomidine; xylazine; atipamezole; cats.

\section{ESTUDO COMPARATIVO DOS EFEITOS DA MEDETOMIDINA E XILAZINA EM GATOS E REVERSÃO COM ATIPAMEZOLE}

\section{RESUMO}

Os objetivos deste estudo foram comparar os efeitos clínicos e sobre a glicemia induzidos pela medetomidina e xilazina em gatos saudáveis e demonstrar a reversão destes efeitos pelo atipamezole. Um estudo prospectivo cego randomizado foi usado com vinte e quatro gatos adultos saudáveis. Os animais foram alocados em 4 grupos de 6 animais cada para receber por via intramuscular (IM): Grupo M (medetomidine - 50 mg/kg; Grupo X (xylazine - 1,1 mg/kg); Grupo o MA (medetomidine - $50 \mu \mathrm{g} / \mathrm{kg}$ e 60 minutos após atipamezole - $0.2 \mathrm{mg} / \mathrm{kg}$ ); Grupo XA (xylazine - 1,1 mg/kg e 60 minutos após atipamezole $0,2 \mathrm{mg} / \mathrm{kg}$ ). Temperatura retal, freqüência respiratória, freqüência cardíaca, pressão arterial sistólica, eletrocardiograma, pressão intraocular, grau de sedação, foram medidos a 0, 30, 60, 120 e 180 minutos, e a concentração de glicose sérica medido a 0,60,120 e 180 minutos. A xilazina a uma dose de 1,1 mg/kg e medetomidina a uma dose de $50 \mu \mathrm{g} / \mathrm{kg}$ (ambos por via intramuscular) induziu hipotermia, freqüência cardíaca, respiração e pressão arterial sanguínea diminuída e também bloqueio atrioventricular de $1^{0}$ grau em alguns gatos, mas não interferiu significativamente com pressão intraocular. A medetomidina induziu hipotermia, sedação e hiperglicemia mais pronunciada quando comparada a xilazina em gatos. $O$ atipamezole foi um excelente antagonista dos efeitos induzidos por medetomidina e xilazina em gatos. Também, não interferiu com os valores de pressão intraocular.

Palavras-chave: medetomidina; xilazina; atipamezole; gatos. 


\section{INTRODUCTION}

The $\alpha_{2}$ agonists activate the central $\alpha_{2}$ receptors, decreasing the release of dopamine and norepinephrine; inducing sedation, analgesia, mydriasis, bradycardia, hypothermia, transient hyperglycemia, polyuria, vomiting and intestinal impaction (MAZE; TRANQUILLI, 1991; RUFFOLO et al., 1994; SINCLAIR, 2003). They can also act on $\alpha_{1}$ receptors (SINCLAIR, 2003) stimulating the sympathetic adrenergic $\alpha_{1}$ post-receptors located in the walls of arteries and veins causes initial hypertension followed by hypotension (RUFFOLO et al.,1994).

In veterinary medicine, the first agonist to be used was xylazine, followed by romifidine, detomidine, medetomidine and more recently dexmedetomidine (SINCLAIR, 2003; MURRELL; HELLEBREKERS, 2005; GRANHOLM et al., 2006).

Synthesized in 1962, xylazine is a potent $\alpha_{2}$ agonist and a weak $\alpha_{1}$ adrenergic agonist. Medetomidine is a potent $\alpha_{2}$-selective adrenergic agonist and has a predominant action in the central nervous system. Medetomidine shows higher $\alpha_{2} / \alpha_{1}$ receptor selectivity than xylazine (VAINIO, 1989; VIRTANEN et al., 1989). Structurally, due to its imidazoline ring it may also have affinity to bind to the imidazoline receptors (VIRTANEN et al., 1989; MAZE; TRANQUILLI, 1991; SINCLAIR, 2003). Atipamezole is considered a new generation $\alpha_{2}$-adrenergic antagonist because of its greater $\alpha_{2}$-adrenergic selectivity (VIRTANEN et al., 1989). This substance has no significant interaction with other types of receptors. In cats, it was proven to be a very potent and selective $\alpha_{2}$-adrenergic antagonist (VAHA-VAHE, 1990).

The objective of this study was to compare the sedative, cardiac, respiratory and endocrine effects in cats after the use of $\alpha_{2}$-adrenergic agonists, medetomidine and xylazine and the reversal of those effects by atipamezole.

\section{MATERIALS AND METHODS}

The experiment was approved by the Ethical Committee of Unoeste (protocol n.016/07). In total, 24 mixed-breed adult healthy cats (14 males and 10 females), obtained from the UNOESTE cat facility, and with a mean age of 3 years and a mean weight of $3.3 \pm 5.1 \mathrm{~kg}$ were used. After the experiment all of the cats were put in the pet program for adoption of the University. The cats were deemed healthy by full blood work and physical exam. One day before running the experiment, the cats were socially isolated and held in individual stainless steel cages under a 12:12 artificial light-dark cycle. The room temperature was about $25^{\circ} \mathrm{C}$ and they were fed ad libitum with dry commercial diet. Two observers (always the same along the experiment) manipulated the cats in this acclimatization period (24 hours before the experiment) to get familiar with them. The information was blinded on whether the experimental group the observer was evaluating.

The cats were randomly allocated into 4 groups of 6 animals each as follows: Group M

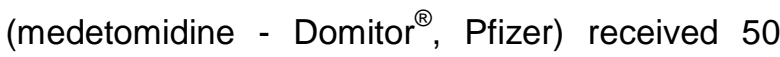
$\mu \mathrm{g} / \mathrm{kg}$ intramuscularly (im) at a $1 \mathrm{mg} / \mathrm{mL}$ concentration and $0.1 \mathrm{ml} / \mathrm{kg}$ in physiologic saline solution $0.9 \%$ (Physiologic saline solution $0.9 \%{ }^{\circledR}$, Fresenius Kabi) 60 minutes later; Group $X$ (xylazine - Ronpum ${ }^{\circledR}$, Bayer) received $1.1 \mathrm{mg} / \mathrm{kg}$ im at a $20 \mathrm{mg} / \mathrm{mL}$ concentration and $0.1 \mathrm{ml} / \mathrm{kg} \mathrm{im}$ physiologic saline solution $0.9 \% 60$ minutes later; Group MA (medetomidine/atipamezole Antisedan ${ }^{\circledR}$, Pfizer) received medetomidine at same dose and concentration of Group M and atipamezole $0.2 \mathrm{mg} / \mathrm{kg}$ im at a $5 \mathrm{mg} / \mathrm{ml}$ concentration 60 minutes later; Group XA (xylazine/atipamezole) received xylazine at same dose and concentration of Group $X$ and atipamezole $0.2 \mathrm{mg} / \mathrm{kg}$ im at a $5 \mathrm{mg} / \mathrm{ml}$ concentration 60 minutes later. 
The values of temperature $(T)$, respiratory rate $(R R)$, heart rate $(H R)$, systolic arterial pressure (SAP), electrocardiogram (ECG), intraocular pressure (IOP) and degree of sedation (DS) were measured at time zero (T0) before the administration of the $\alpha_{2}$-adrenergic agonists; and 30, 60, 120 and 180 minutes after the administration of the $\alpha_{2}$-adrenergic agonists. DS was considered: (0) absent, (1) discreet - low ataxia and protective reflexes present, (2) moderate - reduced protective reflexes and ataxia, and (3) high - lateral decubitus and protective reflexes reduced or absent. Mean interval for sedation return (MISR) was considered to be the time (min) necessary for the animal to recover protective pupillary, palpebral, and interdigital reflexes (ANDRADE et al, 2006). The animal had to stand up without ataxia after the atipamezole administration. The data was always assessed by two observers. Adverse effects as vomiting, diarrhea, sialorrhea, diuresis, vocalization, tremors, and 3rd eyelid prolapse were evaluated at the end of the treatments.

Systolic arterial pressure was measured by an indirect or non-invasive method with Doppler Ultrasonic equipment (Parks Medical-841-A). The transducer was placed on the palmer surface of the left forelimb over the common digital branch of the radial artery to detect blood flow, and a blood pressure monitoring cuff with a width $37 \%$ the limb circumference was placed half way between the elbow and the carpus (GRANDY et al., 1992; BINNS et al., 1995; SPARKES et al., 1999). An electrocardiogram of the cats in right lateral recumbency was recorded (Cardiotest EK51). A mean value of 5 consecutive heart beats was recorded on lead II (paper speed of $50 \mathrm{~mm} / \mathrm{s}, 1$ $\mathrm{cm}=1 \mathrm{mv}$ ) for each parameter. The cardiac rhythm was evaluated by occurrence of a) sinusal; b) sinusal arrhythmia; c) sinusal bradycardia; d) 1st degree A-V block; or e) sinus arrest (TILLEY; GOODWIN, 2001). For IOP measurements, applanation tonometry using a Perkins tonometer (Clement Clarke) was completed. There was instillation of one drop of anesthetic eye drop and one drop of fluorescein eye drop before the exam (ANDRADE et al., 2009). The serum glucose was measured at $0,60,120$ and 180 minutes after administration of the $\alpha_{2}$ agonists. The blood samples were collected by jugular puncture.

The variables were measured between the different groups and compared using an analysis of variance (ANOVA) with contrasts using the Tukey method. An identical procedure was used to compare the different times within each group. Variables that did not show a normal distribution by the Kolmogorov and Smirnov test were submitted to the Kruskal-Wallis test for comparison between the groups and the Friedman test for comparison between the moments. In both cases, contrasts of Dunn were used. A significance level of $P<0.05$ was adopted.

\section{RESULTS}

Both medetomidine and xylazine decreased temperature significantly from 30 to $180 \mathrm{~min}$ compared to the baseline (T0). Medetomidine induced hypothermia more significantly than xylazine at 120 and $180 \mathrm{~min}(P<0.05)$. This effect was reduced by atipamezole, with temperatures returning close to basal values in $180 \mathrm{~min}$ (Table 1).

The $\alpha_{2}$ agonist's administration reduced the respiratory rate from $160 \mathrm{~min}$ to $180 \mathrm{~min}$ compared to the T0. However, this decreased RR was abolished in groups receiving atipamezole (Table 1).

Heart rate was decreased by medetomidine from $30 \mathrm{~min}$ to $120 \mathrm{~min}$ and by xylazine from 30 $\min$ to $180 \mathrm{~min}$. Atipamezole reestablished HR after $120 \mathrm{~min}$ (Table 1). Medetomidine and xylazine decreased SAP from 120 to $180 \mathrm{~min}$ 
compared to the T0. Atipamezole was efficient in reversing this situation (Table 1 ).

There was no statistical difference with the use of medetomidine, xylazine, or atipamezole in the IOP measured values (Table 1). Concerning the variable degree of sedation (DS), medetomidine and xylazine induced high DS from 30 to $60 \mathrm{~min}$, moderate DS for $120 \mathrm{~min}$ and discreet DS at $180 \mathrm{~min}$. After atipamezole administration, the DS returned to absent (Table 2).

Cardiac rhythm was affected by medetomidine at $30 \mathrm{~min}$ and by xylazine at $60 \mathrm{~min}$ (Table 2). After atipamezole administration, the cardiac rhythm was normal for cats (sinusal). Some cats presented with 1st-degree A-V block during the experiment (one cat in group $M$, two cats in group MA, one cat of Group $X$ and one cat in group $X A)$.

Regarding the glucose variables, the $\alpha_{2}$ agonists increased glucose levels in all groups (Table 3), but this effect was more significant with medetomidine from 60 to $180 \mathrm{~min}$. Medetomidine induced hyperglycemia until the end $(249.7 \pm 170.4$ $\mathrm{mg} / \mathrm{dL})$, while xylazine only induced hyperglycemia for $120 \mathrm{~min}(141.0 \pm 52.3 \mathrm{mg} / \mathrm{dL})$ (Table 3). Cats receiving atipamezole reestablished these earlier levels at $120 \mathrm{~min}$.

The mean interval for sedation return (MISR) was significantly increased with medetomidine $(123.5 \pm 410.1 \mathrm{~min})$ compared to xylazine $(87.5 \pm 35.9 \mathrm{~min})(P<0.05)$. The MISR was drastically reduced by atipamezole in both groups, and there was no significantly difference $(P>0.05)$ between group MA $(2.0 \pm 1.0 \mathrm{~min})$ and group XA (2.5 $\pm 1.2 \mathrm{~min})$.

The other clinical signs investigated as vomit, sialorrhea, tremor and 3rd eyelid prolapse are shown in Table 4.

\section{DISCUSSION}

Cats are very susceptible to hypothermia with the use of $\alpha_{2}$ adrenergic agonists (MICHELL, 1994). Alpha-adrenergic agonists induce hypothermia because they affect the thermoregulation center in the hypothalamus (MACDONALD; SCHEININ, 1995).

The decrease in respiratory rate that may occur is due to the $\alpha_{2}$-adrenergic inhibition of the state neurons located in the ventral portion of the brain (RUFFOLO et al., 1994; SINCLAIR, 2003). At high doses of $\alpha_{2}$-adrenergic agonists can reduce the sensitivity of the breathing center to increased $\mathrm{PCO}_{2}$, accentuating breathing depression (MICHELL, 1994). In the experiment the respiratory rate in relation to the basal values, maintained inside of the physiologic limits for the species, doesn't tend clinical relevance, independent of the administration of the atipamezole.

Heart rate was depressed in all groups for 30 min after administration. It was also shown that the mean heart rate of animals treated with atipamezole showed a relative increase. An increased heart rate induced by $\alpha_{2}$ antagonist adrenergics is consistent with other author's descriptions in cats (NILSFORS; KVART, 1996). Some authors reported that medetomidine causes similar but more severe cardiopulmonary effects than xylazine (NILSFORS; KVART, 1996; PYPENDOP; VERSTEGEN, 1998; SINCLAIR, 2003), but in the present experiment, the effects observed in RR, HR and SAP induced by medetomidine and xylazine are very similar. The decrease in systolic blood pressure is due to the depressant effect of xylazine on the heart rate and contractility, resulting in a decreased cardiac output (GREENE; THURMON, 1988; PADDLEFORD; HARVEY, 1999).

Medetomidine has been shown to induce a higher degree of sedation than xylazine. This difference is probably due to its increased affinity 
and selection of the central pre-synaptic $\alpha_{2}$ receptors (SINCLAIR, 2003; CULLEN, 1996). The $\mathrm{\alpha}_{2}$ adrenergic agonists depress the central nervous system, causing a reduction in the release of noradrenalin centrally and peripherally. Furthermore, they promote sedation and muscle relaxation by inhibition of interneural medullary transmission (MAZE; TRANQUILLI, 1991). There was rapid reversal of sedation in the groups treated with atipamezole. This was due to its excellent antagonist selectivity for $\alpha_{2}$ receptors (VAHA-VAHE, 1990).

Arrhythmias caused by $\alpha_{2}$-adrenergic are probably due to reduced CNS sympathetic tonus and increased parasympathetic activity (PADDLEFORD; HARVEY, 1999; PYPENDOP; VERSTEGEN, 1998). In this experiment, only sinusal arrhythmia and 1 st $A-V$ block were observed. It is important to emphasize, that in this study only 5 consecutives HR and ECG readings were made and no others cardiovascular parameters were taken as longer ECG strips or holter monitors, so some arrhythmias might be missed during all the experimental time.

There was no effect of xylazine at a dose of $1.1 \mathrm{mg} / \mathrm{kg}$ IM and medetomidine at a dose of 50 $\mu \mathrm{g} / \mathrm{kg}$ IM on the measured values of the IOP. These findings are consistent with the use of medetomidine in dogs (VERBRUGGEN et al., 2000). In cats, the topical use of medetomidine and xylazine decreases IOP (BURKE; POTTER, 1986a; BURKE; POTTER, 1986b; JIN et al., 1991).

The cats showed significant hyperglycemia after medetomidine administration from $60 \mathrm{~min}$ until $180 \mathrm{~min}$. This finding is in agreement with others reports (BURTON et al., 1997; KANDA; HIKASA, 2008) that hyperglycemia induced by medetomidine is greater than xylazine in cats and that cats are more susceptible to hyperglycemia induced by $\alpha_{2}$ adrenergic agonists than dogs. Induction of hyperglycemia occurs through inhibition of the secretion of insulin, which is mediated by $\alpha_{2}$-adrenergic receptors; specifically, the subtype $\alpha_{2 D}$ is located in the pancreatic islets (ANSAH et al., 1998; ABU-BASHA et al., 1999; KANDA; HIKASA, 2008). There was a reversal of hyperglycemia in the groups treated with atipamezole. Atipamezole is capable of reversing hyperglycemia induced by $\alpha_{2}$ adrenergic agonists.

The MISR showed significant differences between the experimental groups. Animals treated with medetomidine showed a greater duration of sedation compared to those treated with xylazine. Medetomidine and xylazine induced sedation, analgesia and muscle relaxation dose-dependent and very significant in cats (CULLEN, 1996). Although the difference was not significant, there was a quicker reversal after administration of atipamezole in the MA group than in the XA group. It is important to report that all the animals recovered very well from medetomidine and xylazine sedation, in spite of some side effects they have been observed in the experimental groups and they be described in the Table 4.

Xylazine at a dose of $1.1 \mathrm{mg} / \mathrm{kg}$ and medetomidine at a dose of $50 \mu \mathrm{g} / \mathrm{kg}$ (both intramuscular) did not interfere significantly with intraocular pressure. They induced hypothermia, sinusal arrhythmia, 1st-degree A-V block, decreased heart rate, respiration and blood arterial pressure. Medetomidine induced hypothermia, sedation and more prolonged hyperglycemia than xylazine in cats. Atipamezole was an excellent antagonist of the effects induced by medetomidine and xylazine in cats. Also, it did not interfere with the measured IOP values.

\section{ACKNOWLEDGEMENTS}

The authors thank the post-graduate program of UNOESTE for financial support and Pfizer laboratory for donation of medetomidine and atipamezole. 


\section{REFERENCES}

ABU-BASHA, E.A.; YIBCHOK-ANUN, S.;HOPPER, D.L.; HSU, W.H.Effects of the pesticide amitraz and its metabolite BTS 27271 on insulin and glucagon secretion from the perfused rat pancreas: involvement of $\alpha_{2 D}$-adrenergic receptors. Metabolism. v. 48, n. 11, p.146-149, 1999. http://dx.doi.org/10.1016/S00260495(99)90160-9.

ANDRADE, S.F. SAKATE, M.; LAPOSY C.B.; SANGIORGIO, F. Yohimbine and atipamezole on the treatment of experimentally induced amitraz intoxication in cats. International Journal of Applied Research in Veterinary Medicine vol. 4, n. 3, p.2000-2008, 2006.

ANDRADE, S.F.; CREMONEZI, T.; ZACHI, C.A.M.; LONCHIATI, C.F.; AMATUZZI, J.D.; SAKAMOTO, K.P.; DE ARRUDA MELLO, P.A.; ANDRADE, S. F. Evaluation of the Perkins ${ }^{\circledR}$ handheld applanation tonometer in the measurement of intraocular pressure in dogs and cats. Veterinary Ophthalmology. v.12, n. 5, p. 277284, 2009. http://dx.doi.org/10.1111/j.1463$\underline{5224.2009 .00702 . x}$

ANSAH, O.B.; RAEKALLIO, M.; VAINIO, O. Comparison of three doses of dexmedetomidine with medetomidine in cats following intramuscular administration. Journal of Veterinary Pharmacology and Therapeutics, v. 21, n. 5, p. 380-387, 1998. http://dx.doi.org/10.1046/.1.13652885.1998.00155.x

BINNS, S.H.; SISSON, D.D.; BUOSCIO, D.A.; SCHAEFFER, D.J. Doppler ultrasonographic, oscillometric sphygmomanometric, and photoplethysmographic techiniques for noninvasive blood pressure measurement en anesthetized cats. Journal of Veterinary Internal Medicine, v. 9, n. 6, p. 405-414, 1995. http://dx.doi.org/10.1111/j.1939-

1676.1995.tb03301.x
BISTNER, S.I.; FORD, R.B.; RAFFE, M.R. Handbook of veterinary procedures and emergency treatments. $7^{\text {nd }}$ ed. Philadelphia : WB Saunders, 2000. p.259-439.

BURKE, J.A.; POTTER, D.E. Ocular effects of a relative alpha 2 agonist (UK-14,304-18) in cats, rabbits and monkeys. Current Eye Research. v. 5, n. $9, \quad$ p. $\quad 665-676, \quad 1986$. http://dx.doi.org/10.3109/02713688609015134 BURKE, J.A.; POTTER, D.E. The effects of xylazine in rabbits, cats, and monkeys. Journal of Ocular Pharmacology, v. 2, n. 1, p. 9-21, 1986. http://dx.doi.org/10.1089/jop.1986.2.9

BURTON, SL.; LEMKE, K.A., IHLE, S.L., MACKENZIE, A.L. Effects of medetomidine on serum insulin and plasma glucose concentrations in clinically normal dogs. American Journal of Veterinary Research, v. 58 , n. 12 , p. 1440-1442, 1997.

CULLEN, L.K. Medetomidine: sedation in dogs and cats: a review of its pharmacology, antagonism and dose. British Veterinary Journal. v.152, n. 5, p. 519-535, 1996. http://dx.doi.org/10.1016/S0007-1935(96)80005-4

GRANDY, J.L.; DUNLOP, C.I.; HODGSON, D.S.; CURTIS, C.R.; CHAPMAN, P.L. Evaluation of the doppler ultrasonic method of measuring systolic arterial blood in cats. Am. J. Vet. Res. v.53, n. 7, p. 1166-1169, 1992.

GRANHOLM, M.; MCKUSICK, B.C.; WESTERHOLM, F.C.; ASPEGRÉN, J.C. Evaluation of the clinical efficacy and safety of dexmedetomidine or medetomidine in cats and their reversal with atipamezole. Veterinary Anaesthesia and Analgesia. v. 33, n. 4, p. 214223, 2006. http://dx.doi.org/10.1111/i.14672995.2005.00259.x

GREENE， S.A.; THURMON; J.C. Xylazine-a review of its pharmacology and use in veterinary medicine. Journal of Veterinary and 
Pharmacology Therapeutics, v. 11, n. 4, p. 295313, 1988. http://dx.doi.org/10.1111/j.13652885.1988.tb00189.x

JIN, Y.; WILSON, S.; ELKO, E.E.; YORIO, T. Ocular hypotensive effects of medetomidine and its analogs. Journal of Ocular Pharmacology, v. 7, n. $4, \quad$ p. $285-296, \quad 1991$. http://dx.doi.org/10.1089/jop.1991.7.285

KANDA, T.; HIKASA, Y. Neurohormonal and metabolic effects of medetomidine compared with xylazine in healthy cats. Canadian Journal of Veterinary Research, v. 72 , n. 3, p. 278-286, 2008.

KANEKO, J.J., HARVEY, J.W., BRUSS, M.L. Clinical Biochemistry of Domestic Animals. $5^{\text {nd }}$ ed. San Diego: Academic Press, 1997.

MACDONALD, E.; SCHEININ, M. Distribution and pharmacology of alpha 2-adrenoceptors in the central nervous system. Journal of Physiology and Pharmacology, v. 46, n. 3, p. 241-258, 1995.

MAZE, M.; TRANQUILI, W. Alpha-2 adrenoceptor agonists: defining the role in clinical anesthesia. Anesthesiology. v. 74, n. 3, p. 581-605, 1991. http://dx.doi.org/10.1097/00000542-199103000$\underline{00029}$

MICHELL, A.R. Physiology in: Hall LW. Taylor PM. Anesthesia of the cat. $1^{\text {st }}$ ed. London: Balliere Tindal, p. 33-34, 1994.

MURRELL, J.C.; HELLEBREKERS, L.J. Medetomidine and dexmedetomidine: a review of cardiovascular effects and antinociceptive properties in the dog. Veterinary Anaesthesia and Analgesia, v. 32, n. 3, p. 117-127, 2005. http://dx.doi.org/10.1111/j.1467-

2995.2005.00233.x

NILFORS L.; KVART, C. Preliminary report on the cardiorespiratory effects of the antagonist to detomidine, MPV-1248. Acta Veterinaria
Scandinavica Supplementum. v.82, p. 121-129, 1996.

PADDLEFORD, R.R.; HARVEY, R.C. Alpha 2 agonist and antagonist. Veterinary Clinics of North America. Small Animal Practice, v. 29, n. 3, p. 737-746, 1999.

PYPENDOP, B.H.; VERSTEGEN, J.P. Hemodynamic effects of medetomidine in the dog the dose titration study. Veterinary Surgery, v. 27, n. $\quad 6, \quad$ p. $612-622, \quad 1998$. http://dx.doi.org/10.1111/j.1532950X.1998.tb00539.x

RUFFOLO, R.R. JR.; STADEL, J.M.; HIEBLE, J.P. Alpha adrenoceptors recent developments. Medicinal Research Review, v. 14, n. 2, p. 229270, 1994.

http://dx.doi.org/10.1002/med.2610140204

SINCLAIR, M.D. A review of the physiological effects of $\alpha 2$-agonist related to the clinical use of medetomidine in small animal practice. Canadian Veterinary Journal, v. 44, n. 11, p. 885-897, 2003.

SPARKES, A.H. CANEY, S.M.; KING, M.C.; GRUFFYDD-JONES, T.J. Inter- and intraindividual variation in Doppler ultrasonic non invasive blood pressure measurement in healthy cats. Journal of Veterinary Internal Medicine, v.13, n. 4 , p. 314-318, 1999.

TILLEY, L.P.; GOODWIN, J.K. (2001): ECG for the Small Animal Practitioner. $3^{\text {nd }}$ ed. Philadelphia.Saunders.

VAHA-VAHE, A.T. Clinical effectiveness of atipamezole as a medetomidine antagonist in cats. Journal of Small Animal Practice, v.31, n. 4, p. 193-197, 1990.

VAINIO, O. Introduction to the clinical pharmacology of medetomidine. Acta Veterinaria Scandinavica, v. 85, p.85-88, 1989.

VERBRUGGEN, A.M. AKKERDAAS, L.C.; HELLEBREKERS, L.J.; STADES, F.C. THE 
Table 2. Medians (quartiles P25;P75) of the variables degree of sedation and cardiac rhythm according to the different intervals of time.

\begin{tabular}{lcccccc}
\hline Variable & Group & \multicolumn{5}{c}{ Time (minutes) } \\
\cline { 2 - 7 } & & $\mathbf{T 0}$ & $\mathbf{T 3 0}$ & $\mathbf{T 6 0}$ & T120 & T180 \\
\hline $\begin{array}{c}\text { Degree of } \\
\text { Sedation }\end{array}$ & $\mathbf{M}$ & $0(0 ; 0) \mathrm{Aa}$ & $3(2 ; 3) \mathrm{Bb}$ & $3(2 ; 3) \mathrm{Bb}$ & $2(1 ; 2) \mathrm{Cc}$ & $1(1 ; 2) \mathrm{Dd}$ \\
& $\mathbf{X}$ & $0(0 ; 0) \mathrm{Aa}$ & $3(2 ; 3) \mathrm{Bb}$ & $3(2 ; 3) \mathrm{Bb}$ & $0(0 ; 0) \mathrm{Aa}$ & $0(0 ; 0) \mathrm{Aa}$ \\
& $\mathbf{X A}$ & $0(0 ; 0) \mathrm{Aa}$ & $3(2 ; 3) \mathrm{Bb}$ & $3(2 ; 3) \mathrm{Bb}$ & $0(0 ; 0) \mathrm{Aa}$ & $0(0 ; 0) \mathrm{Aa}$ \\
\hline \multirow{3}{*}{ Cardiac rhythm } & $\mathbf{M}$ & $1(1 ; 1) \mathrm{Aa}$ & $2(2 ; 4) \mathrm{Bb}$ & $2(2 ; 2) \mathrm{Bb}$ & $1(1 ; 1) \mathrm{Aa}$ & $1(1 ; 2) \mathrm{Aa}$ \\
& $\mathbf{M A}$ & $1(1 ; 1) \mathrm{Aa}$ & $2(1 ; 2) \mathrm{Bb}$ & $2(1 ; 4) \mathrm{Bb}$ & $1(1 ; 1) \mathrm{Aa}$ & $1(1 ; 2) \mathrm{Aa}$ \\
& $\mathbf{X}$ & $1(1 ; 1) \mathrm{Aa}$ & $1(1 ; 1) \mathrm{Aa}$ & $2(1 ; 4) \mathrm{Bb}$ & $1(1 ; 2) \mathrm{Aa}$ & $1(1 ; 1) \mathrm{Aa}$ \\
& $\mathbf{X A}$ & $1(1 ; 1) \mathrm{Aa}$ & $1(1 ; 2) \mathrm{Aa}$ & $2(1 ; 4) \mathrm{Bb}$ & $1(1 ; 1) \mathrm{Aa}$ & $1(1 ; 1) \mathrm{Aa}$
\end{tabular}

Degree of Sedation was considered: (0) absent, (1) discreet - low ataxia and protective reflexes present, (2) moderate - less protective reflexes and ataxia, and (3) high - lateral decubitus and protective reflexes reduced or absent

Cardiac rhythms: sinusal (1). sinusal arrhythmia (2). sinusal bradycardia (3). 1st-degree A-V block (4). sinus arrest (5). Normal rhythm: sinusal (TILLEY and GOODWIN, 2001).

Upper-case letters compare groups at a same time (Kruskal-Wallis test).

Lower-case letters compare times within each group (Friedman test).

Same letters indicate no significant difference $(P>0.05)$.

The $\alpha_{2}$-adrenergic antagonists were administrated at T60 in the MA and XA groups.

Table 3. Means and standard deviations (Means $\pm S D$ ) of the variable glucose, according to the different intervals of time.

\begin{tabular}{cccccc}
\hline Variable & Group & \multicolumn{4}{c}{ Time (minutes) } \\
\cline { 2 - 6 } & & T0 & T60 & T120 & T180 \\
\hline \multirow{3}{*}{ Glucose } & $\mathbf{M}$ & $75.8 \pm 21.1 \mathrm{Aa}$ & $168.3 \pm 170.7 \mathrm{Bb}$ & $223.0 \pm 108.8 \mathrm{Bc}$ & $249.7 \pm 170.4 \mathrm{Bc}$ \\
\cline { 2 - 6 } & $\mathbf{M A}$ & $73.1 \pm 9.9 \mathrm{Aa}$ & $137.7 \pm 57.6 \mathrm{Cb}$ & $91.0 \pm 30.7 \mathrm{Dc}$ & $66.7 \pm 8.5 \mathrm{Aa}$ \\
\cline { 2 - 6 } & $\mathbf{X}$ & $72.9 \pm 13.0 \mathrm{Aa}$ & $132.8 \pm 37.1 \mathrm{Cb}$ & $141.0 \pm 52.3 \mathrm{Cb}$ & $110.1 \pm 46.3 \mathrm{Cb}$ \\
\cline { 2 - 6 } & $\mathbf{X A}$ & $74.3 \pm 10.1 \mathrm{Aa}$ & $141.0 \pm 35.3 \mathrm{Cb}$ & $79.2 \pm 25.8 \mathrm{Aa}$ & $63.2 \pm 9.7 \mathrm{Aa}$ \\
\hline
\end{tabular}

Reference values: glucose (73-134 mg/dL) (KANEKO, 1997).

Upper-case letters compare groups at each time (Kruskal-Wallis test).

Lower-case letters compare times within each group (Friedman test).

Same letters indicate no significant difference $(P>0.05)$.

The $\alpha_{2}$-adrenergic antagonists were administrated at T60 in the MA and XA groups.

Table 4. Number (and percentage) of cats showing clinical signs after the administration of protocol treatment of each experimental group.

\begin{tabular}{ccccc}
\hline Groups & Vomit & Sialorrhea & Tremors & 3rd Eyelid Prolapse \\
\hline $\mathbf{M}$ & 3 & 2 & 0 & 3 \\
& $(50.0 \%)$ & $(33.3 \%)$ & $(0 \%)$ & $(50.0 \%)$ \\
\hline MA & 1 & 2 & 1 & 0 \\
& $(16.7 \%)$ & $(\%)$ & $(\%)$ & $(0 \%)$ \\
\hline $\mathbf{X}$ & 4 & 3 & 1 & 1 \\
& $(66.7 \%)$ & $(50.0 \%)$ & $(16.7 \%)$ & $(16.7 \%)$ \\
\hline $\mathbf{X A}$ & 5 & 3 & 1 & 0 \\
& $(83.3 \%)$ & $(50.0 \%)$ & $(16.7 \%)$ & $(0 \%)$ \\
\hline
\end{tabular}

Data from 6 cats each group.

The $\alpha_{2}$-adrenergic antagonists were administrated at T60 in the MA and XA groups 